\title{
Language Aesthetics in Serat Kridhasmara by Raden Mas Ngabehi Wangsa Sarsana as Local Language Heritage
}

\author{
Kusuma Retnaningtyas Pertiwi', Sahid Teguh Widodo ${ }^{2}$, and Kundharu Saddhono ${ }^{3}$ \\ \{Kusumarp12@gmail.com ${ }^{1}$, sahidteguhwidodo@yahoo.com ${ }^{2}$, kundharu@uns.ac.id $\left.{ }^{3}\right\}$ \\ 1,2,3 Javanese Language and Literature Program, Postgraduate of Universitas Sebelas Maret \\ J1. Ir. Sutami No. 36A Karuh, Surakarta 57126, Indonesia
}

\begin{abstract}
Javanese song is a literary work in the form of Javanese poetry from the past that has a beauty in every word. Language aesthetics can be used for local language heritage so that local languages are not displaced by other languages. One of the literary works contained in language aesthetics is Serat Kridhasmara. This paper aims to describe the sound aspects of the language in Serat Kridhasmara. Serat Kridhasmara is a text by Raden Mas Ngabehi Wangsa Sarsana, an abdi ndalem (a servant) mantri sewu in Surakarta. This text contains stories about Pakubuwana X and his wife, Kangjeng Putri Mas. This study uses the library research method. The data source used in this study is the Manuscript of Serat Kridhasmara. While the data is divided into primary data, text of Serat Kridhasmara, and secondary data, namely books that have a connection with this research. Through this method, the results obtained in Serat Kridhasmara include aesthetic values of language including purwakanthi guru swara, purwakanthi guru sastra, and lumaksita in each array of pupils. The Purwakanthi can be used for local language herritage so that the Javanese language is not displaced by other languages.
\end{abstract}

Keywords: Language Heritage, Language Aesthetics, Serat Kridhasmara, Purwakanthi

\section{INTRODUCTION}

Literary work is a work of art that cannot be separated from the aspects of beauty in it. In every literary work, especially poetry, a poet will build his work through poetry (typography), diction, imagination, concrete words, majas or figurative language, and verification [1]. Javanese song is a literary work in the form of Javanese poetry in the past that has beauty in every word. All literary power is in the simplest word or sentence [2]. Words and sentences in literary works contain the uniqueness of aesthetic codes which are characterized by the use of language as an aesthetic medium. Aesthetic values can be felt if we are sensitive and vulnerable to the structure and style of language contained in it [3]. Aesthetics is not only talking about the beauty that appears, but also something abstract can be reached in the study 
of aesthetics [4]. One that can be studied in aesthetic studies is the language in literature. Literary work is a form of the author's words containing certain intentions, which will be conveyed to literary connoisseurs [5].

Words in literature are able to have the power to express their aesthetics. Aesthetics is the science of beauty which plays an important role in literary works [6]. Language aesthetics is a study of stylistics. Stylistics is a part of linguistics or according to researchers classified as applied linguistics [7]. Stylistic study is an approach used to analyze typical languages commonly used by an author. Typical language does not mean that literary language is different from daily language and the language used in writing scientific work [8]. This characteristic is in the process of selecting and compiling the words. This is a process of selection, manipulation, and combination in the use of the words.

One of the literary works which have a language aesthetics is the manuscript of Serat Kridhasmara (SK) by Raden Mas Ngabehi Wangsa Sarsana, an abdi dalem (a servant) mantra sewu in Surakarta. SK is kept at the Sonobudoyo Yogyakarta Museum with the catalog number P.B.C 103. The manuscript in the shape of a song with a number of seven pupuh is estimated to be around 100 years old. This information was obtained through the Behrend catalog and historical evidence that Pakubuwana X (PB X) and Kangjeng Putri Mas were married on October 27, 1915 M. Through this information, it was concluded that SK was written no less than $1915 \mathrm{M}$. SK contains seven pupuh, each of which has different subtitles.

SK that contained or told about PB X's journey in leading a kingdom and his love journey with Kangjeng Putri Mas, the son of Hamengkubuwana VII. The first pupuh (Pangudang) tells when PB X began to fall in love with Kangjeng Putri Mas. The second pupuh (Panyandra) tells when PB X always thinks of Kangjeng Ratu Mas. The third pupuh (Pamiluta) tells when PB X began to fall into disarray and begged God to match with a woman he loved. The fourth pupuh (Pantara), the author tells of PB X visiting the Sultan Palace (Keraton Yogyakarta) and after back to Surakarta, he sought wangsit through his servants in the palace. The fifth pupuh (Pangudarasa) tells PB X which seeks to carry out its obligations as Muslims, namely by carrying out or conducting Friday prayers. The sixth pupuh, which is titled Panambung Carita, recounts when PB X invited his wife, Kangjeng Ratu Mas to go around to see his territory. And the last pupuh, seventh, which is titled Pangela-ela, is written when PB X is a husband whose understanding in which it proven when he wants to be invited by his wife to take a boat accompanied by his soldiers to Sumenep, Madura and stay in Surabaya in order to surround his territory.

SK is a literary work which have aesthetic values of language. This manuscript had previously been studied by Purwanti (2016) with the title "Serat Kridhasmara: A Philological Review". In his research, Purwanti only produced SK texts that were clean of errors. In contrast to previous research, this study focuses on the aesthetic study of the language in Serat Kridhasmara and the aesthetic value of the language used as a local language heritage.

Culture and heritage are wealth symbols of spiritual and intellectual for all civilizations, because culture is an expression of human values where it helps to create and build identity [9]. Culture can also be defined as a dynamic value system of learning elements that contains assumptions, agreements, beliefs, and rules that allow group members to relate to others [10]. Literary and cultural works are open systems that are closely related because literature is an integral part of culture [11]. However, even so, as owners of local culture, they must continue to preserve the culture or heritage of their ancestors so that they are not displaced by other cultures.

Recently, the community is facing a fairly complex polemic about the shift or mixing between local culture and other cultures. In Javanese culture, there is local wisdom as a strong 
driver in the life of Javanese people [12]. The Javanese language has thousands of vocabulary and beauty. One of these beauties lies in the SK text. Therefore, it is very necessary to study the aesthetics of the language in the SK manuscript by Raden Mas Ngabehi Wangsasarsana as a local language heritage, so that Javanese language does not occur in extinction.

\section{METHOD}

This research uses a stylistic approach, is an approach that begins with a systematic analysis of the language system of literature, and it is followed by an interpretation of its characteristics that seen from the aesthetic goals of the literary work. The form of this research is qualitative descriptive, namely a descriptive qualitative approach that merely describes and reports the object of research based on data as it is. The type of research used in this study is library research. Library research is research carried out in the research study room or in the library, where the researcher obtains the object of his research through books relating to the topic and research studies [13]. The data source in this study is the SK text. While the data used in this study is divided into primary data and secondary data. Primary data is the main research data, namely SK text that is clean of errors. While secondary data is supporting data for research, namely relevant documents are used for reference in this study.

\section{RESULT AND DISCUSSION}

In literal, stylistic comes from English: stylistic, which means the study of the style of 'language style' or 'stylish language'. As for the term, stylistic is the science that examines the use of language and language style in literary works [14]. It can be said that stylistic is the process of analyzing literary works by examining the elements of language as a literary medium used by writers so that it can be seen how the literary treatment of language in order to put forth subject matter. Therefore, all processes related to the analysis of literary languages are deployed to express linguistic aspects in the literature, such as diction, sentences, use of the language or figurative language, forms of discourse, and other rhetoric medium [15].

One of the aesthetics of the language in SK scripts is the use of purwakanthi in every verse of the song. Purwakanthi is a repetition of sound or sound equation that is famous in Indonesian with the rhyme. The repetition of this sound makes a literary work to be readable. Purwakanthi etymologically derived from the word purwa and kanthi. The word purwa means beginning and kanthi means understanding/using. So that, purwakanthi has the meaning of repetition of sound, either consonant, vocal or word [16]. Purwakanthi consists of a purwakanthi guru swara 'vocal repetition', purwakanthi guru sastra 'consonant repetition', and a purwakanthi guru basa 'repetition of words or syllables' [16].

\subsection{Purwakanthi Guru Swara}

Purwakanthi guru swara is the vocal sound repetition (sound or sound equation) in a lyric or poem. Purwakanthi guru swara in Indonesian is identical to the poem assonance, which is a poem based on the final sound of a syllable or vocal repetition [17]. Purwakanthi guru swarar is a vocal vowel in the language of Java such as [a], [i], [u], [e], [ê] and [o]. SK in purwakanthi guru swara have as many as 46 purwakanthi. Here is an example of a text excerpt that there is purwakanthi guru swara:

(1) Para tamu agung alit (SK/Pupuh1/Pada6)

'The great and young guests' 
(2) Nistha papa tanpa karya (SK/Pupuh5/Pada10)

'The bad work without result'

In Data (1) and (2), there is a purwakanthi guru swara showing vocal assonance [a] in the first and last syllable. The vowel [a] asonance contained in the above data gives the beauty and the dimensions of each of the lyrics. Besides giving beauty, the [a] asonance also raises the rhythmic sound of every word.

(3) Athi-athi malipit pan kadi (SK/Pupuh2/Pada5)

'The neat hear in his pelipis'

(4) Kalih ari kalih ratri (SK/Pupuh6/Pada1)

'Two days two nights'

In Data (3) and (4), there are purwakanthi guru swara [i] open and closed. Open is in the last syllable in the words 'athi-athi', 'kadi', 'ari', and 'ratri'. While closed is in the last syllable in the words "malipit" and "kalih". The repetition of the assonance [i] on the two lines shows the integration or interrelationship between words in each line, so that it gives a rhythmic impression when it read.

(5) Ayuswa wolulas taun (SK/Pupuh1/Pada13)

'Eighteen years old'

(6) Sumawur tinempuh timur (SK/Pupuh6/Pada13)

'Spreading to east'

In Data (5) and (6), there are close purwakanthi guru swara [u]. Close assonance is in the middle with the last. The utilization of the $[\mathrm{u}]$ assonance in each line brings words and presents rhythmic sounds that are very aesthetic when it read.

(7) Legek kateres marlesu (SK/Pupuh1/Pada15)

'Being very tired at that time'

(8) Penet supeket ngrangkepi (SK/Pupuh4/Pada16)

'determining in order to near to equip'

Data (7) and (8) are purwakanthi guru swara in a vocal [e]. There is an open and closed assonance. The existence of $[\mathrm{u}]$ asonance in those line can create aesthetic or aesthetic effect and show the coherence of sounds in every words.

(9) Supados sami kraos (SK/Pupuh4/Pada2)

'have the same feeling'

Data (9) is closed-ended purwakanthi guru swara [o]. There is closed assonance in the words "supados" and "raos" which emphasize when it read, so that the words are very rhythmic.

\subsection{Purwakanthi Guru Sastra}

Purwakanthi guru sastra is based on literary or lettered equations in one song or poem. In Indonesian, purwakanthi guru sastra is identical with the poem of the alliteration namely poem based on the syllable equation of the beginning or the beginning of the consonant [17]. In SK there are 104 purwakanthi guru sastra. Purwakanthi guru sastra is very much found in it and those are the most purwakanthi in SK. There are purwakanthi guru sastra with 
consonant letters $[\mathrm{ng}],[\mathrm{r}],[\mathrm{t}],[\mathrm{m}],[\mathrm{d}],[\mathrm{n}],[\mathrm{s}],[\mathrm{p}],[1],[\mathrm{c}],[\mathrm{k}],[\mathrm{y}],[\mathrm{w}]$, and $[\mathrm{g}]$. Here are excerpt of the text in purwakanthi guru sastra:

(10) Sinawung kanthining kidung (SK/Pupuh1/Pada1) 'it written in the form of poetry'

Data (10) uses the consonant of purwakanthi guru sastra [ng] at the end of syllables. The repetition beautifies the pronunciation.

(11) Sarira rurus araras (SK/Pupuh1/Pada19) 'the beautiful person who makes happy'

The data (11) shows the consonant rhythm [r] followed by the vocal sound [i] and [a] which gives the sound of the speech.

(12) lamat-lamat duk umyat esthane (SK/Pupuh2/Pada4) 'slowly for quickly stepping'

Data (12) shows a repetition of consonant [t] after [a] vowel sound that gives the beautiful sound of the speech.

(13) muncar amancorot (SK/Pupuh2/Pada10) 'the shining ray'

The data (13) shows the repetition ofconsonant [c] after the consonant sound [n] which gives the beautiful sound of the speech.

(14) dhasar sampun gusti kawistareng semu (SK/Pupuh3/Pada16) 'god have made convincing the ray'

The data (14) shows the reconstruction of the [s] consonant in the middle and last syllable that gives the beautiful sound of the speech.

(15) marma sareng amba tampi (SK/Pupuh4/Pada11) 'the affection will be accepted by us'

Data (15) shows the repetition of consonant $[\mathrm{m}]$ in the middle of a word that gives the beautiful sound of the speech.

\subsection{Purwakanthi Lumaksita or Purwakanthi Basa}

Purwakanthi lumaksita or purwakanthi basa is the repetition of the word, either in whole or in part, either experiencing or not undergoing a change of form, either in one line or in a different sequence but still in sequence [18]. There are 15 purwakanthi lumaksita in SK. The repetition of the sound is one syllable and the two syllables contained in one line. Here is an example of repetition of the syllables:

(16) labet kagubet ing tresna (SK/Pupuh1/Pada3) 'because of falling in love' 
Data (16) shows that purwakanthi lumaksita is in the form of a repetition of the word 'bet' in the word 'labet' and in the word 'kagubet'. Repetition of the syllable 'bet' creates a rhythmic impression and functions to create the beauty of sound when they read or developed.

(17) sumunu sumunar wening (SK/Pupuh1/Pada17) 'spouting the clearness'

Repetition of the syllable "sumu" in the data (17) that occurs in the words "sumunu" and "sumunar" emphasize or give the impression of beauty in the speech.

(18) memanise nursing sita/ sitannya manuku ening (SK/Pupuh1/Pada20)

'the sweetness is felt into the heart'

'the heart is always faithful in a silent'

In Data (18), there is a repetition of 'sita' syllable that occurs at the end of the line and the beginning of the next line. This reinforces and beautifies the pronunciation of the song.

In Serat Kridhasmara, there are 165 utilization of sound aspect (Assonance, Alliteration, and Purwakanthi Lumaksita) that consist of 46 aspects of sound assonance (Purwakanthi Guru Swara), 104 aspects of alliteration sounds (Purwakanthi Guru Sastra), and 15 aspects of Purwakanthi Lumaksita sound.

Based on the information in the above, it can be seen that the dominance of the use of purwakanthi guru sastra is much more than the use of purwakanthi guru swara and lumaksita. The dominant vowel sound sequence found in SK is vowel sound [a], while the dominant consonant sound found in SK is consonant or alliteration [ng]. Purwakanthi lumaksita between 1 syllable and 2 syllables have very thin differences.

Purwakanthi is a beauty of the language used by authors to beautify their creations. The beauty of the language can be used as a heritage of a language so that it does not wear off in the age. Language has a very diverse role. The role of language is very dominant in human life because language is not only a part of human culture but also a determinant of the development of culture itself [19]. As in the journal entitled "Javanese Language as the Revealer of the Local Diversity of Samin Communities in Blora Regency", it is clear that language has a very big role to preserve a culture. Language itself is also a cultural heritage that needs to be maintained so that other cultural values are maintained.

If the language heritage is not preserved, sooner or later the language will shift its position. As in the article entitled "Trends in Naming System on the Javanese Society: a Shift From Javanese to Arabic" in which discussing the use of the name Java shifted into an Arabic name. Today's society, especially Javanese people are very enthusiastic about naming their children with Arabic names rather than Javanese names [20]. This is the impact of the lack of Javanese heritage. Even though the Javanese name is a Javanese community identity. If the heritage of the language is not preserved, surely one day it will be lost of the times. This was also felt by the Sentani people who lost their traditional expression because no one inherited the Sentani language. In an article entitled "Local Diversity of Sentani Communities, Papua in Traditional Expressions", it explains that the loss of the traditional expression is because of many people do not know or memorize the Sentani language [21]. The case can be used as a mirror for purwakanthi use in Javanese. If the Javanese heritage in the form of purwakanthi is not preserved, it will definitely experience a shift like the traditional Sentani expression. Even though such a language heritage is rich in ancestral words. 
The inheritance of language greatly influences the identity of the society. This is discussed in a journal entitled "Navigating between Ethnic and Religious Identity, Heritage Language Maintance among Young Australians of Indonesian Origin" which explains that language heritage is ethnic identity and religious identity when the language is maintained in the outside society [22]. Therefore, a language heritage is needed to be preserved so that the identity of a society is maintained. As the same as the language heritage contained in the SK. SK has a language heritage which includes purwakanthi guru swara, guru sastra, and lumaksita which currently very few people know about it. Therefore, the aesthetic languages like this is very necessary to be preserved as an ancestral language heritage so that the Javanese language identity does not wear off in the age [23].

\section{CONCLUSION}

Based on the research with the study of aesthetic language in SK, there are three types of sound aspects that found in it. These aspects of sound are purwakanthi guru swara, purwakanthi guru sastra, and purwakanthi lumaksita. There are 46 purwakanthi guru swara which include asonance [a], [i], [u], [e], and [o]. There are 104 purwakanthi guru sastra who cover $[\mathrm{ng}],[\mathrm{t}],[\mathrm{r}],[\mathrm{m}],[\mathrm{d}],[\mathrm{n}],[\mathrm{s}],[\mathrm{p}],[\mathrm{l}],[\mathrm{c}],[\mathrm{k}],[\mathrm{y}],[\mathrm{w}]$, and $[\mathrm{g}]$. While purwakanthi lumaksita or guru basa in SK with total number 15. The sound aspect is an aesthetic language which when it read, it will appear rhythmic and very beautiful sounds.

The language aesthetics contained in the SK is a heritage of the language inherited from the ancestors which is very necessary to be preserved. The language aesthetics is a noble language that is rich in meaning and has a very strong power. Besides being rich in meaning, the aesthetics of the language contained in the SK are a Javanese people's identity. In order to avoid a shift in language heritage and loss of Javanese people's identity, it is necessary to preserve Javanese heritage. The preservation of Javanese can be done through various Javanese manuscripts that contain language aesthetics and the noble pits of the Javanese ancestors.

\section{REFERENCE}

[1] Larlen.. Nilai Estetika Puisi Dua Pintu Kita dan Batu Pelangi. Jurnal Pena 2 (3) ISSN 2089-3973: 97-117. 2010

[2] Miller, J Hill. On Literature Aspek Kajian Sastra. Diterjemahkan Anissa Ismayasari. Yogyakarta: Jalasutera. 2011.

[3] Ritawati, Tengku. Pantun in the text of Nyanyian Lagu Melayu Asli (NLMA). Jurnal Harmonia: Journal of Arts Research and Education 18 (1): 97-106 DOI: 10.15294/harmonia.v18i1.15524. 2018.

[4] Sugiarti. Estetika dalam Novel Jatisaba Karya Ramayda Akmal. Jurnal Litera, 15 (1): 100-110. DOI: 10.21831/ltr.v15i1.976. 9. 2016.

[5] Munir, Saiful. Diksi dan Majas dalam Kumpulan Puisi Nyanyian dalam Kelam karya Sutikno W.S: Kajian Stilistika. Jurnal Sastra Indonesia 2 (1): 1-10. ISSN 2252-6315. 2013.

[6] Wulananda, Ramadhaniar. Estetika profetik Novel Muhammad: Lelaki Penggenggam Hujan karya Tasaro G.K sebagai Sumber Pendidikan Karakter. Jurnal Pendidikan: Teori, Penelitian, dan Pengembangan 1 (7): 1350-1363. DOI: 10.17977/jp.v1i7.6564. 2016.

[7] Subroto, Edi. Kajian Stilistika Teks Bahasa Pedalangan Wayang Purwa Gaya Surakarta. Jurnal Bahasa dan Seni 41 (2): 143-158. 2013. 
[8] Ratna, Nyoman Kutha. Stilistika, Kajian Puitika Bahasa, dan Budaya. Yogyakarta: Pustaka Pelajar. 2009.

[9] Yusoff, dkk. Preservation of Intangible Cultural Heritage Using Advance Digital Technology: Issues and Challenges. Jurnal Harmonia: Journal of Arts Research and Education 16 (1): 1-13 DOI: 10.15294/harmonia.v16i1.6353. 2016.

[10] Muqoyyidin, Andik Wahyun. Dialektika Islam dan Budaya Lokal Jawa. Jurnal Kebudayaan Islam 11 (1): 1-18 DOI: 10.24090/IBDA.V11/1.64. 2013.

[11] Saddhono, Kundharu. Sekar Suluk Babaraning Ngelmi Makrifat Wasiyat Kala Kanjeng Nabi Kilir: Kajian Sikap Hidup dan relevansinya bagi Masyarakat Modern. Jurnal AlTahrir 13 (1): 1-20 DOI https://doi.org/10.21154/al-tahrir.vl3il.4. 2013.

[12] Saddhono, Kundharu. Sekar Macapat Pocung: Study of Religious Values Based on Javanese Local Wisdom. Jurnal El Harakah 20 (1): 15-32 DOI: 10.18860/el.v20i1.4724. 2018.

[13] Semi. Atar. Metode Penelitian Sastra. Bandung: Angkasa. 1993.

[14] Abrams, M.H. 1979. The Mirror and the Lamp: Romantic Theory and the Critical Tradition. New York: Oxford University Press.

[15] Cuddon, J.A. 1979. A Dictionary of Literary Term. Great Britain: W\&J Mackay Limited.

[16] Padmosoekotjo, S.1953, Ngrengrengan Kasusastraan Jawa. Jogjakarta: Hien Hoo Sing.

[17] R.S. Subalidinata. 1968. Sarining Kasusastran Djawa. Jogjakarta: P.T. Jaker.

[18] Saputra, Karsono H. 2001. Puisi Jawa Struktur dan Estetika. Jakarta: Wedatama Widya Satra.

[19] Mardikantoro, Hari Bakti. 2013. Bahasa Jawa Sebagai Pengungkap Kearifan Lokal Masyarakat Samin di Kabupaten Blora. Jurnal Komunitas 5 (2): 197-207. DOI: 10.15294/komunitas.v5i2.2738

[20] Herawati, Nanik. 2016. Trends in Naming System on Javanese Society: A Shift From Javanese to Arabic. Jurnal Lingua Cultura 10 (2): 117-122 DOI: 10.21512/lc.v10i2.1730

[21] Yektiningtyas, Wigati. 2017. Kearifan Lokal Masyarakat Sentani, Papua dalam Ungkapan Tradisional. Jurnal Atavisme 20 (2): 237-249 DOI: 10.24257/atavisme.v20i2.396.237-249

[22] Muslim, Ahmad Bukhori. 2016. Navigating Between Ethnic and Religious Identity Heritage Language Maintenance Among Young Australians of Indonesian Origin. Indonesian Journal of Applied Linguistics 6 (1): 145-155. DOI: dx.doi.org/10.17509/ijal.v6i1.2747

[23] K. Saddhono, "Language of Coastal Communities in the Northern Coast of Central Java: Sociolinguistic Studies in Cultural Integration Maritime-Agrarian Perspective." Adv. Sci. Let. vol. 23 no. 10 pp 10054-10056, 2017 